УДК: 72.033.4...4; 72.033 .5

ББК: 85.11

DOI:10.18688/aa155-4-44

\author{
Roberta Cerone
}

\title{
Cives romani in marmoris arte periti: the Classical World and the Renewal of the Cloister Model in $13^{\text {th }}$ century Rome
}

In Central and Southern Italy the cloister appeared later than in Central Europe and Rome was no exception in this regard ${ }^{1}$. The oldest one surviving, in fact, is the eastern wing of the cloister in the Cistercian abbey of Tre Fontane ad aquas salvias, dated to the second quarter of the $12^{\text {th }}$ century ${ }^{2}$, but it's only during the second half of the century that this element had a moderate spread in the city, as shown by the cases of S. Maria Nova [23], S. Cecilia in Trastevere [41, pp. 81-82] and S. Lorenzo fuori le mura (Ill. 71). The latter is the only certainly dated, thanks to the indication of the Liber Pontificalis that assigns it to the time of Pope Clement III (1187-1191) and more precisely to the year $1189^{3}$. The structures of S. Maria Nova and S. Cecilia, however, should not be placed too far from S. Lorenzo, as evidenced by the similar characteristics of the three monuments: the uncovered brick masonry, the use of the crowning cornice with elements in brick and marble in progressive projection, the type of quadrangular pillar with a marble frame, the preference for the single columnette with pulvin capital ${ }^{4}$. In particular, these characters suggest to ascribe those cloisters to the same workshops that built the Roman bell towers, in which we find the same structural and decorative elements [39-40].

By the early $13^{\text {th }}$ century, however, the appearance of the Roman cloisters changes radically. The key moment in this evolution is represented by the southern and eastern wings of the cloister in S. Scolastica in Subiaco ${ }^{5}$, one of the papal stronghold on the border with the

In Central Europe the presence of the cloister is attested by the High Middle Ages, while in Central and Southern Italy the first cloisters appear only in the middle of the 11th century in the main monasteries of the area, as S. Scolastica in Subiaco at the time of the abbot Umbertus (1051-1060), Montecassino under the abbot Desiderius (1058-1086) and S. Martino sul Monte Acuziano near Farfa at the time of Berardus II (1090-1099) [35, p. 705; 36] .

2 It is important to remember that in the same period a cloister, now disappeared, is also recalled at $\mathrm{S}$. Giovanni in Laterano [17]. The east wing at Tre Fontane precedes of at least thirty years the northern gallery of the same complex [3, pp. 149-157; 43, p. 22].

3 In this site the erection of the porch enclosure started a long building season culminated in the years of Pope Honorius III (1216-1227), which changed the face of the sanctuary [1].

${ }_{4}$ If in S. Lorenzo the double columns underlined the central arch of the poliforae, in S. Cecilia and S. Maria Nova there is a preference for the simpler one column solution, but equipped with a plastic furniture that, at least in the better preserved case of S. Cecilia, is homogeneous compared with the case of S. Lorenzo. Particularly significant is the type of capital used in S. Cecilia, similar to those used in the north wing of Tre Fontane, which supports its dating to the second half of the century [41, pp. 81-82].

According to the recent hypothesis [38]. 
Kingdom of Sicily and then closely related to Urbe, both in cultural and political terms ${ }^{6}$. The artist signature states immediately who is the responsible for the innovations to the prototype: Magister Iacobus, the second member of a famous family of marble workers, the so-called "Cosmati". These artists reworked motifs and forms derived from the classical world and used marbles obtained from ancient monuments, conscious that they gathered an important heritage from the Roman times. Therefore, they proudly proclaim their romanitas in the inscriptions that accompanied their creations: they call themselves Romani Cives in marmoris arte periti in the wings realized in the twenties of the $13^{\text {th }}$ century by Cosma, son of Magister Iacobus, again in S. Scolastica in Subiaco ${ }^{8}$ or Magistri doctissimi romani in the porch of Civita Castellana Cathedral, built in 1210 by Iacobus with the partnership of his son [14].

As is well known, since the $11^{\text {th }}-12^{\text {th }}$ century the workshops of marble workers were usually engaged in realizing pavements and liturgical furniture for Roman churches but, at the beginning of the $13^{\text {th }}$ century, the role of these artists increased up to cover also architectural planning. In this regard, the work of Iacobus in Subiaco, realized between 1202 and 1205 [38], is precisely one of their first attempts in this new field of activity. In Subiaco cloister the traditional model was transformed in an antique style (Ill. 72): all the usual elements are present, but they take unusual appearance. Moreover, there is a new attention towards the plastic equipment with the insertion of coupled columns to mark the eurhythmy of the poliforae and the use of phytomorphic motifs on the capitals, for the most part still the pulvin type. Furthermore, the uncovered brick masonry of the previous models is abandoned for a refined marble covering mainly made by remains from the Villa of the emperor Nero (54-68 a. C.), which stood just nearby in Subiaco valley [19]. Another novelty is the insertion of the mosaic band, now almost entirely disappeared, which originally contained an inscription, as shown by the letters remaining marks'. In parallel with the latter case of S. Paolo fuori le mura and S. Giovanni in Laterano, it can be assumed that the inscription reminded the patronage, and perhaps mentioned the symbolic function of the cloister in relation to the regular life ${ }^{10}$. In

\footnotetext{
6 The monastery was one of the twelve abbeys founded in the Aniene Valley, 45 miles east of Rome, in the early $6^{\text {th }}$ century by St. Benedict from Norcia [21].

7 In general about the different families of Roman marble workers see 12, but in particular on Iacobus activity $[5 ; 15 ; 37]$.

According to P. F. Pistilli [38], after the intervention of Iacobus the Subiaco's cloister was finished by Cosma (northern and western wings) in the 1230s, but about the dating of the different wings see also [25; 26, pp. 217-221]. 9 Unfortunately the inscription is not recorded by any source, but still existed in the $18^{\text {th }}$ century as shown by the documents (Roma, Archivo Centrale dello Stato, AA.BB.AA., I vers., Beni delle corporazioni religiose, 1860-1890, b. 24, Relazione sullo stato dei monasteri, 1879).

$10 \quad[38$, p. 240]. Today, the cloister of S. Giovanni in Laterano shows a fragmentary inscription that is entirely known thanks to the old transcriptions [13, pp. 262-263], "Canonicam formam sumentes discite normam. Quam promisistis, hoc claustrum quando petistis. Discite sic esse, tria vobis adesse necesse. Nil proprium, morem, castum servando pudorem. Claustri structura sti vobis docta figura. Ut sic clarescant animae, moresque nitescant". Even in S. Paolo fuori le mura the text refers to the symbolic importance of the monastic enclosure and to the patronage [22]: "Agmina sacra regit locus hic quem splendor honorat. Hic studet atque legit monachorum cetus et orat. Claustrales claudens claustrum de claudo vocatur. Cum Christo gaudens fratrum pia turma seratur. Hoc opus exterius pre cunctis pollet in Urbe. Hic nitet interius monachalis regula turbe. Claustri per girum decus auro stat decoratum. materiam mirum precellit materiatum. Hoc opus arte sua quem Roma cardo beavit natus de Capua Petrus olim Primitiavit. Ardea quem genuit quibus abbas vixit in annis cetera disposuit bene provida dextra Johannis".
} 
any case, due to this new presence, the cloister of Subiaco can be considered the first example of that "speaking vocation" which will become the very essence of the Roman cloister model: a cloister where are not the sculptural elements - mostly aniconic - to evoke the function of the place, but the visual power and the solemnity of the epigraph, whose forms recall the commemorative inscriptions affixed on Roman monuments ${ }^{11}$.

The cloister of Subiaco, furthermore, gave the start to a great renewal of the entire abbey which lasted the whole of the $13^{\text {th }}$ century and it is highly probable that such architectural renovation has been provoked by the stay of Pope Innocent III (1198-1216) in 1202 and by his efforts to reform the local community [18]. After all, the corrective action of this Pope marked other Roman monasteries, involved in the reorganization of their structure: SS. Quattro Coronati, S. Paolo fuori le mura and perhaps S. Saba on the Aventinus hill. In all these cases, in fact, the new building sites started with the construction of a cloister, around which the new residential wings were organized.

The erection of the cloister of San Saba took place during the architectural renovation of the monastery which, once again, was characterized by the intervention of the sculptor Iacobus, who signed the main portal of the church in $1205^{12}$. Unfortunately, today it is not possible to appreciate the innovations of this cloister, which was destroyed in the 1930s, and whose form appeared seriously compromised even in the old photos ${ }^{13}$. The historical plans, however, show the original presence of a ceiling system, a novelty for Roman cloisters that at this time usually had a wooden roof, with the exception of S. Lorenzo and Tre Fontane, in which the vaults supported the upper levels ${ }^{14}$.

The cloister of SS. Quattro Coronati can be dated to the first decade of the $13^{\text {th }}$ century too ${ }^{15}$. In this case, we neither have documentary evidences, nor we know the name of the artist, but it is reasonable to suppose its pertinence at the time of Innocent III and the participation of the Cosmatesque workshops who were often involved in the sites of indirect patronage of the Pope $[29 ; 30 ; 33]$. The first reason is that this site was a priory of S. Croce at Sassovivo near Foligno, one of the key monasteries in the papal reform of the religious life and then, similar to the previous examples, it is highly probable that here too the spiritual reform started the material renewal of monastic structures [31, pp. 239-246].

The second reason is that the appearance of this monument shows ambivalent characters that report their belonging to the experimental phase of the beginning of the century. On the one hand, SS. Quattro Coronati's cloister borrows elements from the tradition of the previous century, such as the blind arcades on corbels or the crowning cornice in brick and marble. At the same time, however, it introduces the marble panelling, although limited compared to

\footnotetext{
11 For an overview on the medieval use of epigraphy see, in particular for the High Middle Ages, 8; 9; 10. 12 Iacobus also realized the protirus and part of the liturgical furniture of the church [24;37].

13 [7]. The old photos representing the cloister are preserved in Roma, Istituto centrale per il catalogo unico, Gabinetto fotografico nazionale.

${ }_{14} \quad$ See for example the plan published in 28, p. 154, fig 14. The vaults appeared in later cloisters of S. Giovanni in Laterano, where the original vaults still exist, and S. Paolo fuori le mura where, on the contrary, they were replaced during a restoration campaign [20].

15 We disagree with the chronology proposed by L. Barelli [4, p. 60], where the SS. Quattro Coronati cloister is linked with that of S. Croce di Sassovivo, realized in 1229 by Petrus de Maria, that seems completely different.
} 
Subiaco; therefore, here we find the exclusive use of the coupled columns and a new type of capital: no more pulvins, but capitals decorated by the vegetal motifs - the so called "nenunfari" leaves - later widely used in other cloisters ${ }^{16}$. We can also observe several antique-style elements that will be used in later cloisters, like the classic pilaster strips placed next to the piers, but, on the other hand, there are experimental patterns that will remain substantially unfulfilled, like the taste for polychromy in the archway soffits ${ }^{17}$ and the peculiar crowning cornice where the corbels alternate with marble sectilia [27].

The Roman model of the cloister culminates in S. Paolo fuori le mura (Ill. 73). In this abbey the erection of the cloister started from 1208 when the reorganization of the monastic wings was undertaken, again connecting with the reform of Innocent III [44]. The gradual evolution of the building site is linked to the delay in completing the porch, whose authorship is still under discussion. It is now established that the construction of the north gallery of the cloister in the 1230s was made by the Vassalletto, another marmorarii family, working at the same time also in S. Giovanni in Laterano ${ }^{18}$. Here, all the novelties previously emerged are fully implemented and improved in the direction of greater monumentality and decorative complexity: the system of vaults, now sadly disappeared, was set on square brackets and, by the side of the windows, on pillars lower than the crowning cornice, creating an unusual rhythm in the interior corridors that is reflected outside in the projection of the supports.

The marble panelling derived from Subiaco and SS. Quattro Coronati is optimized and enriched with new references to the classical world: the lacunars in the intrados, the fluted pilaster strips, the variety of the capitals, the marble sectilia, the lion protomes, the anthropomorphic masks, the mosaics, the frieze of palmettes and triglyphs.

The S. Paolo cloister then resumed the invention of mosaic inscription, which remembers the patrons and declares the aesthetic and symbolic values of this place, stating it explicitly as "the most beautiful of Rome": "hoc opus exterius pre cunctis pollet in Urbe". A perfection exalted by classical forms that symbolically and visually lead back to the role of the Eternal City and to the auctoritas of the Pope of Rome. Romanitas and papal auctoritas: the two main concepts that moved the policy of Innocent III and of his immediate successors interested in bringing back the territories of the Papal State under the aegis of Rome.

Title. Cives romani in marmoris arte periti: the Classical World and the Renewal of the Cloister Model in $13^{\text {th }}$ century Rome.

Author. Roberta Cerone - Ph. D., Postdoctoral Research Fellow. Sapienza Università di Roma. Piazzale Aldo Moro 5, 00185 Roma, Italia. roberta.cerone@uniroma1.it

Abstract. An introduction of the cloister in Rome starts in the $12^{\text {th }}$ century (Tre Fontane, S. Lorenzo fuori le mura, S. Cecilia in Trastevere), but it's only in the $13^{\text {th }}$ century that we find a systematic usage of the cloister as the main element in planning of old and new monastic foundations.

In parallel with its spreading the typical Roman cloister, as it was codified during the $12^{\text {th }}$ century, undergoes a radical change, partly due to the involvement of the different artists of Roman marmorarii families: Cosmati and Vassalletto. These sculptors considered themselves discendants of Classical Rome and, in the name of that heritage, they reinterpreted forms and motifs of architectural sculpture from Roman period through the reuse and the reworking of marbles taken from

16 Like in the capitals of Cosma wings in Subiaco and those in the cloister of S. Sabina on the Aventinus, both built during the 1220s [2].

17 The painting were restored at the beginning of $20^{\text {th }}$ century [32].

18 About the dating of the wings of S. Paolo cloister and the different workshops see [6;12, pp. 126-

138; 16]. For the Vassalletto in the Lateran see [13, pp. 255-273]. 
ancient monuments. This change started in the monastery of S. Scolastica in Subiaco near Rome under the aegis of pope Innocent III and then involved the main complexes of the Urbe.

Keywords: cloisters; medieval Rome; monastery of S. Scolastica at Subiaco; pope Innocent III; Magister Iacobus; Roman marble workers.

Название статьи. Cives romani in marmoris arte periti: античный мир и обновление модели клуатра в Риме XIII века.

Сведения об авторе. Роберта Чероне - Ph. D. , научный сотрудник. Римский университет Ла Сапиенца, Рiazzale Aldo Moro 5, Рим, Италия, 00185. roberta.cerone@uniroma1.it

Аннотация. Появление крытых галерей в Риме относят к XII в. (Монастырь Трех источников, Сан-Лоренцофуори-ле-Мура, Санта-Чечилия-ин-Трастевере), но систематическое использование крытых галерей как основного конструктивного приема в старых и новых монастырских постройках относится к XIII в. По мере распространения типичный римский клуатр радикально изменился, отчасти в результате деятельности художников, представителей римских семей резчиков по мрамору - Козмати и Вассалетто. Эти скульпторы считали себя наследниками классического Рима и во славу этого наследия придавали формам и мотивам римской архитектурной пластики новую интерпретацию, вторично используя и перерабатывая мраморы, взятые с античных памятников. Первые изменения такого рода происходили в монастыре Св. Схоластики Нурсийской в Субиано близ Рима под эгидой папы Иннокентия III, а затем в главном комплексе в Урбе.

Ключевые слова: крытые галереи; средневековый Рим; монастырь Св. Схоластики Нурсийской; папа Инокентий III; магистр Якобус; римские мастера по мрамору.

\section{References}

1. Barclay Lloyd J. The Architecture of the Medieval Monastery of S. Lorenzo fuori le mura, Rome. Architectural studies in memory of Richard Krautheimer. Mainz, Zabern Publ., 1996, pp. 99-102.

2. Barclay Lloyd J. Medieval Dominican Architecture at Santa Sabina in Roma, c. 1219 - c. 1320. Papers of the British School in Rome, 2004, no. 72, pp. 231-292.

3. Barclay Lloyd J. E. Ss. Vincenzo e Anastasio at Tre Fontane near Rome: History and Architecture of a Medieval Cistercian Abbey. Kalamazoo, Cistercian publications Publ., 2006. 324 p.

4. Barelli L. Il complesso monumentale dei SS. Quattro Coronati a Roma. Roma, Viella Publ., 2009. 95 p. (in Italian).

5. Bassan E. Iacopo di Lorenzo. Enciclopedia dell'arte medievale, no. 7, Roma, Treccani Publ., 1996, pp. $246-249$ (in Italian).

6. Bassan E. Larchitettura del monastero e il chiostro dei Vassalletto. San Paolo fuori le mura. Roma, 1988, pp. 223-254 (in Italian).

7. Cannizzaro M. E. Nuove scoperte nella città e nel suburbio. Notizie degli scavi di antichità, 1901, no. 26, pp. 10-14 (in Italian).

8. Cardin L. Scrivere per apparire: tentativi di autorappresentazione nell'epigrafia delle élites a Roma tra VI e IX secolo. La culture du haut Moyen Age une question délites? Turnhout, Brepols Publ., 2009, pp. 101-124 (in Italian).

9. Carletti G. Epigrafia monumentale di apparato nelle chiese di Roma dal IV al VII sec.: dalla lettura alla contemplazione. Atti del VI Congresso Nazionale di Archeologia cristiana (Pesaro - Ancona, 19-23 settembre 1983). Firenze, La nuova Italia editrice Publ., 1986, pp. 275-286 (in Italian).

10. Cavallo G.; Mango C. Prefazione. Epigrafia medievale greca e latina. Ideologia e funzione, Atti del seminario di Erice (12-18 settembre 1991). Spoleto, Cisam Publ., 1995, pp. VII-XIV (in Italian).

11. Cerone R. La regola e il monastero. Arte e architettura in Santa Scolastica a Subiaco (secc. VI-XV). Roma, Campisano editore Publ. (in press).

12. Claussen P. C. Magistri Doctissimi Romani: die römischen Marmorkünstler des Mittelalaters. Corpus Cosmatorum. Stuttgart, Franz Steiner Verlag, 1987. 264 p. (in German).

13. Claussen P. C. Die Kirchen det Stadt Rom im Mittelalter 1050-1300, vol. 2, San Giovanni in Laterano. Stuttgart, Franz Steiner Verlag, 2008, 431 p. (in German).

14. Claussen P. C. Perché non tante facciate come quella di Civita Castellana? Identità, rivalità-periferia, centro. $L a$ cattedrale cosmatesca di Civita Castellana. Atti del convegno internazioanle di studi (Civita Castellana, 18-19 settembre 2010). Roma, L'Erma di Bretschneider Publ., 2012, pp. 233-242 (in Italian).

15. Creti L. In marmoris arte periti. La bottega cosmatesca di Lorenzo tra il XII e il XIII secolo. Roma, Quasar Publ., 2009. 266 p. (in Italian).

16. D’Achille A. M. Il chiostro di S. Paolo fuori le mura, Questioni aperte e prospettive di ricerca. Storie di città e di architetture. Studi in onore di Enrico Guidoni. Roma, Kappa, 2014, pp. 395-414 (in Italian).

17. De Blaauw S. A mediaeval portico at San Giovanni in Laterano: the Basilica and its ancient conventual buildings. Papers of the British School at Rome, 1990, no. 58, pp. 306-313.

18. De Prosperis A. Innocenzo III e i monasteri di Subiaco. Latium, 2008, no. 25, pp. 3-30.

19. Di Matteo F. Villa di Nerone a Subiaco: il complesso dei Simbruina stagna. Roma, L'Erma di Bretschneider Publ., 2005. 186 p. (in Italian).

20. Docci M. Le 'metamorfosi' del chiostro paolino: Giovenale contro Calderini. Quaderni dell'Istituto di Storia dell'architettura, 1999-2002, no. 34-39, pp. 517-524 (in Italian). 
21. Egidi P. Notizie storiche dell'abbazia durante il Medioevo. I monasteri di Subiaco. Roma, 1904, no. 1, pp. 45-184 (in Italian).

22. Fedele P. L'iscrizione del chiostro di S. Paolo. Archivio della Società Romana di Storia Patria, 1921, no 44, pp. 269-276 (in Italian).

23. Gallio P. Il monastero di Santa Francesca Romana (Santa Maria Nova): le vicende storiche di un antico monumento. Bollettino del Centro studi di Storia dellarchitettura, 2005-2007, no. 42-44, pp. 251-253 (in Italian).

24. Gandolfo F. La cattedra papale in età federiciana. Federico II e l'arte del Duecento italiano, Atti della III settimana di studi di Storia dell'arte medievale dell'Università di Roma (15-20 maggio 1978). Galatina, Congedo editore Publ., 1980, no. 1, pp. 339-366 (in Italian).

25. Gandolfo F. sub vocem Cosma di Iacopo di Lorenzo. Dizionario biografico degli italiani, Roma, 1984, no. XXX, pp. 66-69 (in Italian).

26. Gianandrea M. Drudo de Trivio e Luca di Cosma. Gli artisti, le opere e il loro intervento a Civita Castellana. $L a$ cattedrale cosmatesca di Civita Castellana, Atti del Convegno internazionale di studi (Civita Castellana, 18-19 settembre 2010). Roma, L’Erma di Bretschneider Publ., 2012, pp. 217-232 (in Italian).

27. Giorgi E.; Matera F. Il restauro della cornice cosmatesca del chiostro. Dal cantiere dei Ss. Quattro Coronati a Roma. Note di storia e restauro per Giovanni Carbonara. Roma, Viella Publ., 2012, pp. 107-122 (in Italian).

28. Giovenale G. B. Il chiostro medievale di San Paolo fuori le mura. Bullettino della Commissione archeologica comunale di Roma, 1917, no. 46, p. 125-167 (in Italian).

29. Iacobini A. Innocenzo III. Enciclopedia dell'arte medievale, no. 7, Roma, Treccani, 1996, pp. 386-392 (in Italian).

30. Iacobini A. Innocenzo III e l'architettura. Roma e il Nord del Patrimonium Petri. Innocenzo III. Urbs et Orbis, Atti del Congresso internazionale: Roma, 9-15 settembre 1998. Roma, Istituto storico italiano per il Medioevo Publ., 2003, no. 2, pp. 1261-1291 (in Italian).

31. Maccarrone M. Studi su Innocenzo III. Padova, Antenore Publ., 1972, 472 p. (in Italian).

32. Muñoz A. Il restauro della chiesa e del chiostro dei SS. Quattro Coronati, vol. XXXIX, no. 234. Roma, Danesi Publ., 1914 , p. 462 (in Italian).

33. Pace V. La committenza artistica di Innocenzo III: dall'Urbe all'Orbe. Innocenzo III. Urbs et Orbis, Atti del Congresso Internazionale (Roma, 9-15 settembre 1998). Istituto storico italiano per il Medioevo Publ., 2003, no. 2, pp. 1226-1244 (in Italian).

34. Pistilli P. F. L’architettura a Roma nella prima metà del Duecento (1198-1254). Roma nel Duecento. L'arte nella città dei papi da Innocenzo III a Bonifacio VIII. Torino, Seat Publ., 1991, pp. 3-71 (in Italian).

35. Pistilli P. F. Chiostro. Enciclopedia dellarte medievale. Roma, Treccani Publ., 1993, no. IV, pp. 694-718 (in Italian).

36. Pistilli P. F. Il chiostro e l'abbazia: insediamenti monastici nell'Italia altomedievale. Medioevo mediterraneo: l'Occidente, Bisanzio, L'Islam, Atti del Convegno internazionale:Parma, 21-25 settembre 2004. Milano, Electa Publ., 2007, pp. 294-303 (in Italian).

37. Pistilli P.F. Da artista a imprenditore: il magister Iacobus al servizio di Innocenzo III. Medioevo: natura e figura, Atti del XIV Convegno Internazionale di Studi:Parma, 20-25 settembre 2011 (in press).

38. Pistilli P. F.; Cerone R. Labbazia di Santa Scolastica: dal chiostro cosmatesco come adeguamento al more romano alle trasformazioni delle ali monastiche prima della Commenda. De re monastica III. Le valli dei monaci, Atti del Convegno internazionale di studio: Roma - Subiaco, 17-19 maggio 2010. Spoleto, Cisam Publ., 2012, pp. 217-269 (in Italian).

39. Priester A. E. The belltowers of medieval Rome and the architecture of renovatio. Phil dissertation. Princeton University, 1990. $356 \mathrm{p}$.

40. Priester A. E. The Italian campanile. Where did it comes from?, in Pratum romanum. Richard Krautheimer zum 100. Geburstag. Wiesbaden, Reichert Publ., 1997, pp. 259-275.

41. Righetti M. Pasquale I e la fondazione carolingia. Santa Cecilia in Trastevere. Roma, Palombi, 2007, pp. 65-83 (in Italian).

42. Righetti M. Corpus vero Domini defertur in turribus: il repositorio di Fossanova. Arte medievale, s. IV, 2013 , no. 3, pp. 71-86 (in Italian).

43. Romanini A. M. "Ratio fecit diversum": la riscoperta delle tre Fontane a Roma chiave di lettura dell'arte bernardina. Ratio fecit diversum. San Bernardo e le arti, Atti del Congresso internazionale:Roma, 27-29 maggio 1991. Arte medievale, s. II, 1994, vol. 8, no. 1, pp. 1-78 (in Italian).

44. Schuster I. La Basilica e il Monastero di San Paolo fuori le mura: note storiche. Torino, Società ed. Internazionale Publ., 1934 (in Italian). 